\title{
Limited progress in sustainable development: Factors influencing the environmental management and reporting of South African JSE-listed companies
}

\author{
Claudia Kitsikopoulos ${ }^{1}$, Ute Schwaibold ${ }^{1}$ Douglas Taylor ${ }^{2}$ \\ ${ }^{1}$ School of Animal, Plant and Environmental Sciences, Faculty of Science, University of the Witwatersrand, Johannesburg, \\ South Africa \\ ${ }^{2}$ Centre for Environmental Change and Human Resilience, University of Dundee, Dundee, UK \\ Correspondence: \\ Claudia Kitsikopoulos, School of Animal, Plant and Environmental Sciences, Faculty of Science, University of the \\ Witwatersrand, 1 Jan Smuts Avenue, Johannesburg 2000, South Africa. \\ Email: claudia.kitsikopoulos@students.wits.ac.za
}

\begin{abstract}
Although public, governmental, international and stakeholder pressure have led to corporations conforming to better sustainability performance, there has been an insignificant reduction in environmental degradation levels, and progress in sustainable development is limited. This study examines which factors influencing environmental management and reporting in South Africa could potentially contribute to this limited progress. The study was based on a series of interviews with sustainability managers of JSE-listed firms. Results suggest that stock exchange listing requirements, internal processes and structures, experienced staff and the sustainability committee positively influence environmental and overall corporate sustainability, yet that resource and time constraints, as well as reporting fatigue, potentially limit the advancement of sustainable development. This restricts the further reduction of environmental degradation, which is urgently necessary in light of the harmful impacts that for example climate change has on the environment, societies and economies.
\end{abstract}

\section{KEYWORDS}

environmental degradation, environmental management, JSE, progress in sustainable development, stakeholder pressure

\section{INTRODUCTION}

Continuous environmental degradation has led to increased public, stakeholder, governmental and international pressure on corporations to conform to better sustainability performance (Epstein, 2008) and to improve accountability for their social and environmental impact (Charlo, Moya, \& Muñoz, 2013). Corporate attention to sustainable development has grown internationally (Du, Jian, Zeng, \& Du, 2013; Jizi, 2017; Mårtensson 
\& Westerberg, 2016). Sustainable development is of vital importance considering the harmful impacts that climate change has on societies, economies and the environment (IPCC, 2014; Mårtensson \& Westerberg, 2016). Various international organizations such as the Global Reporting Initiative (GRI), the International Organization for Standardization (ISO) and the International Integrated Reporting Framework (IIRC) provide guidelines and frameworks to assist corporations in their stakeholder communication relating to nonfinancial performance. Sustainable stock exchanges (SSEs) such as the New York Stock Exchange (NYSE), Shanghai Stock Exchange (SSE) and Johannesburg Stock Exchange (JSE) have aided in establishing environmental indices, listing rules and financial systems that reflect company sustainability (SSE Secretariat, 2017).

Despite the advances in corporate environmental management practices and a steady increase in corporate non-financial reporting globally (Editorial, 2009; KPMG, 2013), progress in sustainable development and the reduction of environmental degradation levels is limited (Skouloudis, Evangelinos, \& Kourmousis, 2010; Baumgartner, 2011; Bouten, Everaert, Van Liedekerke, De Moor, \& Christiaens, 2011; Jabbour et al., 2012; UN, 2012; Alazzani \& Wan-Hussin, 2013; Comyns, Figge, Hahn, \& Barkemeyer, 2013). One factor influencing this has been related to corporate sustainability management and disclosures becoming merely a modification of business as usual (BAU; Mårtensson \& Westerberg, 2016; Jizi, 2017). Further, regulatory and stakeholder pressures, competitive advantages, and external standards and legitimacy have driven environmental management instead of sustainable development as a central company value (De Silva Lokuwaduge \& Heenetigala, 2017; Deegan, 2014; Jose \& Lee, 2007; Paulraj, 2009; Ramos, Cecílio, Douglas, \& Caeiro, 2013). Extern al pressures can only effectively lead to a transformation of company processes towards more sustainable business practices if internal structures and processes have integrated sustainability into the business strategy and management plans (Baumgartner \& Rauter, 2017; Sullivan \& Gouldson, 2017). Yet ithas been reported that sound environmental management systems, practices and frameworks to track impacts are either absent (Jabbour et al., 2012; Maubane, Prinsloo, \& Van, 2014; Ramos et al., 2013; Skouloudis et al., 2010), not well developed or not well implemented (Searcy, 2016). Too little focus was given to actual improvements (Brammer \& Pavelin, 2006; Skouloudis et al., 2010).

In South Africa, a country that is at present experiencing severe environmental challenges such as water scarcity and increasing temperature anomalies as well as changing frequencies and intensities of severe weather events (Burkett et al., 2014; Christensen et al., 2013; Cisneros et al., 2014; Cubasch et al., 2013; Kirtman et al., 2013), sustainable development was positively influenced by the Johannesburg Stock Exchange (JSE) and the King Codes on Corporate Governance (King I, II, III and IV; Malherbe \& Segal, 2001; JSE, 2010). King II brought the sustainability concept into a business context, encouraging companies to practice environmental responsibility and support a 'precautionary approach to environmental challenges' (IoDSA, 2002, p. 93). King III focused on integrated sustainability reporting, as discussed in Section 9 of the code (IoDSA, 2009). King IV, released in 2016 and effective as of 1 April 2017, makes reference to integration without a strong 
emphasis on environmental reporting (IoDSA, 2016), and positioning sustainable development as one of the fundamental concepts of the report. Despite this initial drive, recently many corporate targets were found to lack ambition and to be short term and operationally rather than strategically focused (CDP, 2016a). Environmental impact and risk reporting were also found to be static (CDP, 2016b; Kitsikopoulos et al., unpublished). Considering this development and that no considerable reduction in environmental degradation levels has been achieved (IPCC, 2014), it is necessary to understand the factors potentially limiting sustainable development progress. Specifically, this study aimed to identify the factors that influence the environmental management and reporting at South African companies based on a series of interviews with sustainability managers of JSE-listed firms. This study contributes to the existing discussions on aspects impacting corporate environmental management and reporting, but also provides evidence to develop a better understanding of this issue in a South African context.

\section{METHODS}

To investigate the factors affecting environmental management and the reporting thereof, a representative sample of $30 \mathrm{JSE}$-listed companies was selected for interview. Companies belonged to six economic groups (resources, 5; basic industries, 4; non-cyclical consumer goods, 5; cyclical services, 5; non-cyclical services, 5; financials, 6; FTSE International, 2002). Greater levels of engagement with sustainability management have been found at large firms, which may be due to the presence of qualified staff, management tools and stakeholder involvement as well as their more significant economic, social and environmental impact (Hörisch, Johnson, \& Schaltegger, 2015). Large listed firms are thus suitable for an analysis of their environmental management and reporting approaches. Accordingly, the selected companies also needed to be part of the JSE Top 100, which are the largest listed firms according to their market capitalization in 2008.

Each company was contacted to request the details of the relevant staff member dealing with environmental management, which was usually the sustainability manager. Sixteen of the 30 companies contacted agreed to participate in this research. The empirical work for this study was carried out in South Africa (Johannesburg, Pretoria and Durban regions) between May and July 2014. Fourteen interviews were held in person while two interviews were conducted over the telephone. Interviews were carried out with sustainability managers or staff involved in the environmental sustainability work of companies in mining, industrial metals and mining, oil and gas producers (resources), construction and materials, forestry and paper (basic industries), food producers (non-cyclical consumer goods), general retailers, travel and leisure, industrial transport (cyclical services), mobile telecommunications (non-cyclical services), banks, non-life insurance, life insurance, financial services and real estate investment trusts (financials).

The semi-structured interviews were focused on obtaining the manager's or staff member's 
perspectives on environmental reporting in their organizations. The interview questions focused on the level of importance of environmental issues at the company, the motivation for environmental management and reporting, and the importance of the sustainability committee for corporate environmental management. Because competencies and experiences have been found to greatly contribute to the successful implementation and management of environmental strategies (Mårtensson \& Westerberg, 2016), the interviewees were asked to outline the criteria used by the company to select new staff for the sustainability department. As both internal communication and the integration of environmental systems in the overall control and structure of the business have been reported to positively influence environmental management (Mårtensson \& Westerberg, 2016; Siebenhüner \& Arnold, 2007), interview questions also covered the following topics based on the King III principles (applicable to companies at the time the research was conducted; IoDSA, 2009): controls present in the company to verify and safeguard the integrity of the integrated annual report (Principle 9.1.1); company efforts to ensure substance over form (Principle 9.1.5) and the role of the audit committee in overseeing assurance of sustainability issues (Principle 9.3.3). While this research was undertaken, King III was applicable to JSE-listed companies. Although it was replaced by King IV, the new principles were only effective on 1 April 2017 (IoDSA, 2016). Hence interview questions were based on King III. An opportunity was given to the interviewee to discuss any concerns or issues around environmental sustainability not covered by the interview schedule.

Ethics clearance was obtained from the University of the Witwatersrand Human (NonMedical) Ethics Research Committee (H13/11/08). The interviews were transcribed and answers were analysed for commonalities and aggregated into key words, phrases and expressions. Percentages were calculated for levels of consensus.

\section{RESULTS}

Eight of the 16 interviewees responded that economic, social and environmental issues are equally important to their company. Only three interviewees said that economic issues outweighed environmental and social issues. The remaining responses varied as to which of the three aspects had more weight in their firm. Both the company responsibility/understanding the importance of environmental issues (55\%) and JSE listing requirements (27\%) were seen as most important in motivating the reporting on environmental issues (Figure 1). 


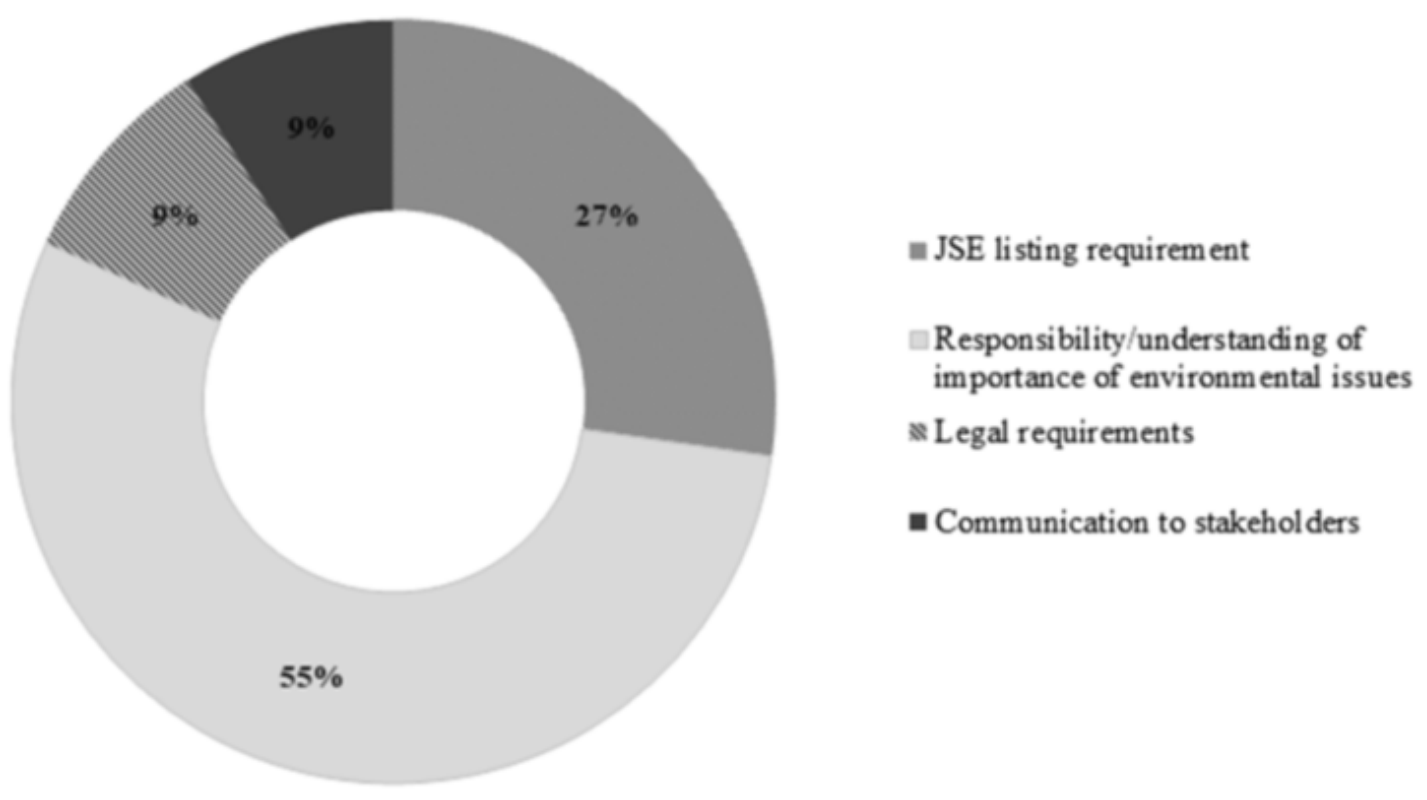

FIGURE 1. Most common reasons provided for reporting on environmental issues in the company

participating companies had sustainability committees (or similar committees) in place. This was either in response to the Companies Act (19\%), which took effect in 2008, in response to King III $(25 \%)$, or for other reasons such as to improve visibility of sustainability, the need for attention at board level or to maximize efficiency (56\%).

The sustainability committee was also seen to improve environmental performance by 15 of the 16 interview participants, as it supports communication to the board, improves company management and awareness and drives company change. One interviewee suggested that the company itself was the driver of sustainability, not the committee.

When selecting newstaff, most companies looked for experience and expertise (52\%) as well as askill mixture (20\%). An understanding of the industry and reporting was another criterion mentioned (16\%). Only a few companies were concerned with qualification (8\%). One company did not have any hiring strategy in place.

Internal assurance was found to be the main control system to verify and safeguard the integrity of integrated reports (46\%; King III Principle 9.1.1; Figure 2). Interviewees also stated that internal verification processes and sound internal company structures play an important role in the management of environmental issues. Substance over form (King III Principle 9.1.5) was achieved in many different ways, and no single standard measure could be identified. The strategies applied by companies included data verification (20\%), reporting of examples in the annual report (20\%), reporting against targets (20\%), identification of materiality $(16 \%)$ and making use of various management systems (12\%), as well as the use of GRI guidelines, King III principles and/or IIRC guidelines (8\%). All 16 companies had an audit committee overseeing the assurance of sustainability issues (King III Principle 9.3.3). Strategies mentioned for Principle 9.1.5 (substance over form) also serve to reinforce this process. 


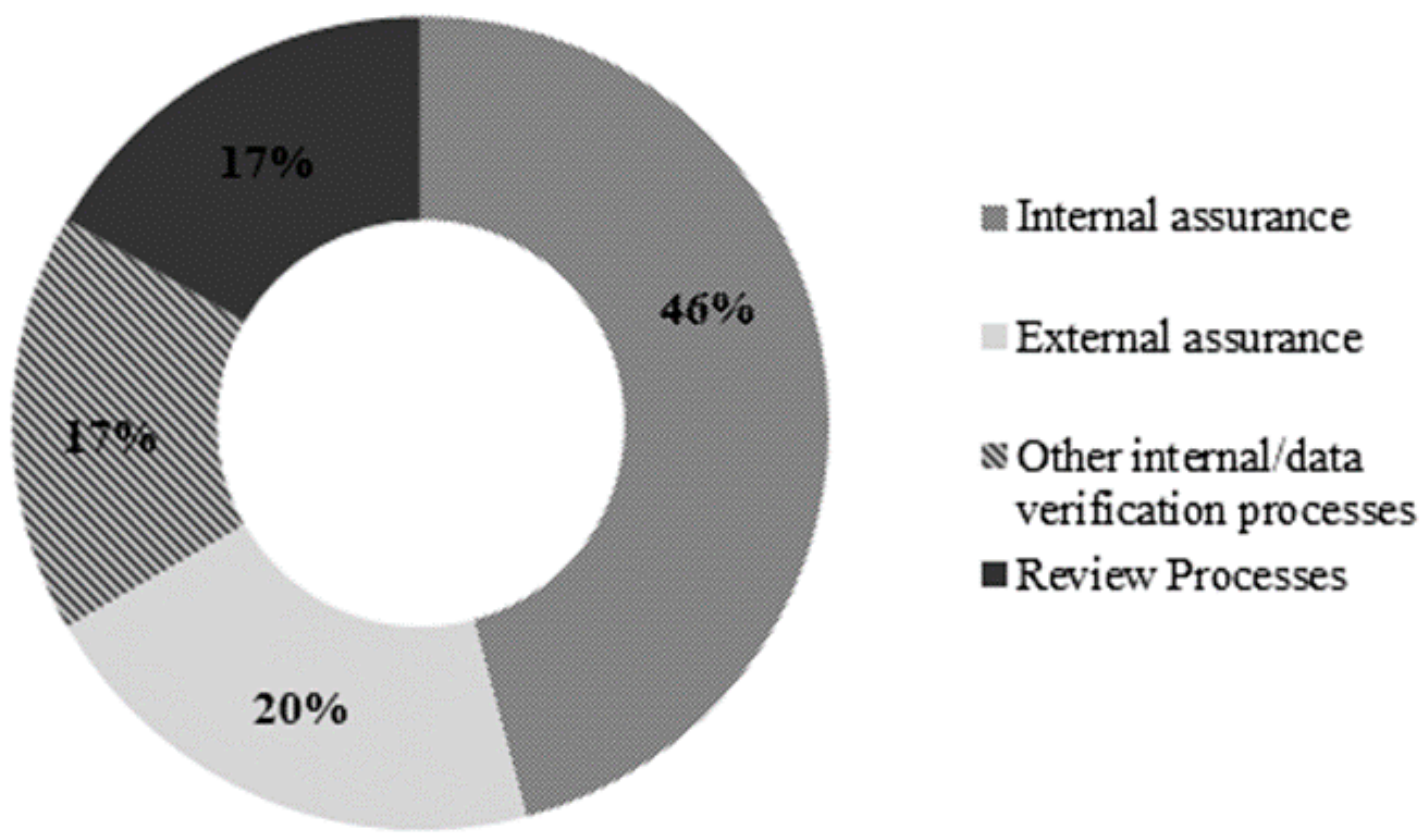

FIGURE 2. Controls present at companies to verify and safeguard the integrity of the integrated annual report.

Being given the opportunity to raise any additional issues, interviewees brought up similar concerns. The following key issues were identified:

- difficulties in determining what is material to the business;

- companies experience reporting fatigue (reporting on, for example, the GRI, Carbon Disclosure Project (CDP, water and carbon), Greenhouse Gas (GHG) Protocol, United Nations (UN) Global Compact, ISO 14000, AA1000 and other industry- and or sectorspecific reporting tools or certification systems such as the Forest Stewardship Council (FSC)) - reporting guidelines available to companies are not necessarily aligned;

- most companies experience cost and resource constraints for managing data and the reporting thereof.

\section{DISCUSSION}

Although most interviewees indicated that economic, social and environmental aspects carried equal weight in their respective companies, it is not clear whether this view was shared across the company, especially at board level. The responses given appeared to be partly dependent on the sector or economic group in which the relevant company operated. Companies within the financial sector, for example, tended to prioritize economic over social and environmental aspects, having the creation of profits for investors as their main goal. Different economic groups and sectors are also exposed to different levels of external pressures (Cho, Guidry, Hageman, \& Patten, 2012; D'Amico, Coluccia, Fontana, \& Solimene, 2016; Mårtensson \& Westerberg, 2016). For example, the JSE at the time distinguished 
between high, medium and low environmental impact companies, depending on which sector they operated in (JSE, 2010, Section 13). Companies in the resources group, among others, were required to report on a wider range of sustainability issues and in more detail than a company operating in the financials group (JSE, 2010, Section 13).

Until a few years ago, companies globally reported on environmental issues for example to increase their competitive advantage, to conform to regulatory and stakeholder pressures or to comply with external standards (De Silva Lokuwaduge \& Heenetigala, 2017; Deegan, 2014; Jose \& Lee, 2007; Paulraj, 2009; Ramos et al., 2013). Research findings here indicate that South African companies mainly report on environmental issues in compliance with JSE listing requirements and because it is viewed as a responsibility or because companies understand the importance of environmental issues. This confirms that external pressures and standards positively influence corporate environmental reporting, as reported previously, and shows that companies aim to abide by the regulatory norms. The results obtained in this study could further indicate that companies may have developed a greater understanding of their responsibility regarding their impacts on natural resources and management needs. This could be verified with departments other than the sustainability department and at board level, and would eliminate the possibility that the outcomes presented here are related to views shared by sustainability managers only. Other studies have identified a lack of reporting by competitors and an absence of interest from stakeholders as possible reasons not to report on environmental issues (Kolk, 2003; Ramos et al., 2013). This concurs with the response given by one interviewee from the financial sector: environmental reporting is held to a minimum as stakeholders have expressed no interest in these matters.

The majority of the companies included in this study have a sustainability committee in place, although the name of the committee may vary among firms. Sustainability committees were identified as playing a vital role in company sustainability management and in communication to both the board and the employees. Such a committee is viewed as necessary in order to include a sustainability approach into the daily operations. Although the King III Code of Corporate Governance does not make mention of such a committee (or similar), it was included inter alia in response to the Companies Act of 2008, which prescribes the appointment of a social and ethics committee (Department of Trade and Industry, 2009). Other research has shown that the presence of a sustainability committee as well as a chief sustainability officer positively affects the disclosure of GHG emissions (Peters \& Romi, 2014). The environmental sustainability function fell within the social and ethics committee in $80 \%$ of companies. This differs from results obtained by Jose and Lee (2007), which showed that only $30 \%$ of the Fortune Global 200 companies had separate environmental committees in place and $18 \%$ were part of the health and safety unit. This may be a result of significant social issues affecting South Africa, which take priority in sustainability management (IRMSA, 2015).

Most corporations value competency and experience when selecting new staff to assist with 
company environmental sustainability. This is in accordance with findings by Mårtensson and Westerberg (2016). Competent and experienced staff are an important factor that can positively influence environmental management and the reporting.

The three King III principles (controls present to verify and safe- guard the integrity of the integrated annual report; ensuring substance over form; assurance of sustainability issues by the audit committee) included in this study give some insight into the internal company systems. As they are listed in Section 9 of the code, they would be important to the reporting and disclosure of company sustainability matters. Interviews revealed that most companies opted for internal verification systems in order to safeguard the integrity of the annual integrated report. Eighty percent of companies included other internal processes and review systems in internal auditing systems. Similarly, interviewees were of the opinion that, in order to manage sustainability issues successfully, a sound internal assurance system is required. This was in response to inquiring about the application of King III Principle 9.3.3 (oversight of the audit committee over the provision of assurance of sustainability issues), which was evident at all companies. It was proposed during the interviews that a company should have a well-functioning and effective internal audit system, as this would indicate a good level of understanding within and between company departments in addition to a well-aligned business strategy. Research supports the notion that well-functioning and well-aligned internal processes and structures and company management systems to run a more sustainable business and positively influence environmental management are very important (Mårtensson \& Westerberg, 2016; Romolini, Fissi, \& Gori, 2014; Siebenhüner \& Arnold, 2007; Songini \& Pistoni, 2012; Sullivan \& Gouldson, 2017). Although, according to the interviewees, the King III principles were followed, the quality of internal verification systems and their level of implementation were not verified here. Future research should assess this quality at South African listed companies. King III further refers to 'substance over form' as a principle (IoDSA, 2009), but leaves it open as to how this can be achieved. The principles do not provide any guidance in this matter. This is reflected in the different strategies employed by the companies. Reporting on data and initiatives seemed to be the main strategy, but there was no clear indication as to how this issue was addressed and achieved.

Another aspect raised was the importance of materiality in the management of environmental issues. It is essential to correctly identify which issues are core to the business strategy and values, and not to allow, for example, the GRI guidelines to define a business. A lack of materiality understanding would in turn mean that the business could first encounter difficulties in understanding how environmental issues affect the business (Barkemeyer, Preuss, \& Lee, 2015). Second, the GRI guidelines might be used as a tick-box system (de Colle, Henriques, \& Sarasvathy, 2014), potentially affecting sustainability reporting quality as well as sustainability management. According to most interviewees, it was necessary to have made mistakes in sustainability management over the past years, as these errors provided the opportunity to better understand materiality and slowly progress 
in the field. Sustainability management and reporting is a journey with constant adjustments to improve the relationship with stakeholders and contribute to sustainable economic growth (Lozano, 2013). This view was also shared by interviewees who participated in this study. Despite this learning curve, annual report analyses (Kitsikopoulos et al., unpublished) indicate that the reporting of key environmental indicators showed no further improvement after 2011.

Reporting fatigue, and resource and time constraints, were two aspects pointed out during interviews that negatively impact on corporate environmental management and reporting. A large number of reporting initiatives and guidelines, such as the GRI, the CDP, the CDP Water Disclosure and the International Organization for Standardization (ISO), are applied by companies. Firms spend a significant amount of time on reporting for both compliance (e.g. legal and listing requirements) and voluntary purposes (e.g. sector competition). The measures these frameworks provide do not always allow for easy comparison between companies within or between sectors (De Silva Lokuwaduge \& Heenetigala, 2017). In addition, aside from the financial year end reporting deadline, the various reporting initiatives and guidelines have their submission dates at different times of the year and are not necessarily aligned in their information or data requirements. Very little time is therefore left for the implementation and management of sustainability initiatives. The clear message sent by interviewees was that reporting is not what sustainability should be about. Cost and resource constraints only add to this problem. An increased need for resources and time for all aspects of environmental management as well as reporting fatigue were also identified by Brown, de Jong, and Levy (2009) and Lozano (2013). More than a decade ago, research had already shown that CEO expectations were not in line with what the sustainability team felt they could achieve: adequate resources and time constraints would impact on the quality of the report and how much information could be disclosed (Adams \& McNicholas, 2007). This internal company issue has not yet been resolved.

Irrespective of whether factors such as adhering to regulatory norms, an understanding of the importance of environmental issues, experienced staff, a sustainability committee and well-aligned internal processes and structures positively influence environmental management, its reporting and overall corporate sustainability, if the staff managing environmental sustainability do not have the necessary resources and time, and are fatigued, environmental management can only be improved to a certain point. This means that progress in environmental management and reporting will ultimately reach a plateau, and annual integrated and sustainability report analyses have shown that the quality of reporting has not improved since 2011 (CDP, 2013; Kitsikopoulos et al., unpublished). It is proposed that by alleviating the reporting fatigue, resource and time constraints that company staff experience when managing and reporting on environmental sustainability further progress in corporate sustainable development can be realized. 


\section{CONCLUSION}

Although corporate environmental management practices have improved and corporate non-financial reporting has increased globally (Editorial, 2009; KPMG, 2013), sustainable development progress was found to be limited (Alazzani \& Wan-Hussin, 2013; Baumgartner, 2011; Bouten, Everaert, Van, De, \& Christiaens, 2011; Comyns et al., 2013; Jabbour et al., 2012; Skouloudis et al., 2010; UN, 2012). Research findings indicate that, although factors such as regulatory norms, an understanding of the importance of environmental issues, experienced staff, a sustainability committee and well-aligned internal processes and structures positively impact the management of company environmental sustainability, reporting fatigue, resource and time constraints potentially limit further progress. These aspects negatively impact on the quality of sustainability management and its reporting quality and, therefore, the extent to which corporate natural resource use can be managed. Yet further progress in sustainable development is urgently needed, considering the harmful impacts climate change has on societies, economies and the environment due to the continuing natural resource degradation.

\section{REFERENCES}

Adams, C. A., \& McNicholas, P. (2007). Making a difference: Sustainability reporting, accountability and organisational change. Accounting, Auditing and Accountability Journal, 20(3), 382-402. https://doi.org/ 10.1108/09513570710748553

Alazzani, A., \& Wan-Hussin, W. N. (2013). Global Reporting Initiative's environmental reporting: A study of oil and gas companies. Ecological Indicators, 32, 19-24. https://doi.org/10.1016/j.ecolind.2013.02.019

Barkemeyer, R., Preuss, L., \& Lee, L. (2015). On the effectiveness of private transnational governance regimes - Evaluating corporate sustainability reporting according to the Global Reporting Initiative. Journal of World Business, 50(2), 312-325. https://doi.org/10.1016/j.jwb.2014.10.008

Baumgartner, R. (2011). Critical perspectives of sustainable development research and practice. Journal of Cleaner Production, 19(8), 783-786.

https://doi.org/10.1016/j.jclepro.2011.01.005

Baumgartner, R., \& Rauter, R. (2017). Strategic perspectives of corporate sustainability management to develop a sustainable organization. Journal of Cleaner Production, 140 (Part 1), 81-92. https:/doi.org/10.1016/ j.jclepro.2016.04.146

Bouten, L., Everaert, P., Van Liedekerke, L., De Moor, L., \& Christiaens, J. (2011). Corporate 
social responsibility reporting: A comprehensive picture? Accounting Forum, 35(3), 187204. https://doi.org/10.1016/j.accfor.2011.06.007

Brammer, S., \& Pavelin, S. (2006). Voluntary environmental disclosures by large UK companies. Journal of Business Finance and Accounting, 33(7/11 8), 1168-1188. https://doi.org/10.1111/j.1468-5957.2006.00598.x

Brown, H. S., de Jong, M., \& Levy, D. L. (2009). Building institutions based on information disclosure: Lessons from GRI's sustainability reporting. Journal of Cleaner Production, 17(6), 571-580. https://doi.org/14 10.1016/j.jclepro.2008.12.009

Burkett, V. R., Suarez, A. G., Bindi, M., Conde, C., Mukerji, R., Prather, M. J., Yohe, G. W. (2014). Point of departure. In C. B. Field, V. R. Barros, D. J. Dokken, K. J. Mach, M. D. Mastrandrea, T. E. Bilir, et al. (Eds.), Climate change 2014: Impacts, adaptation, and vulnerability. Part A: Global and sectoral aspects. Contribution of Working Group II to the Fifth Assessment Report of the Intergovernmental Panel on Climate Change (pp. 169-194). Cambridge: Cambridge University Press.

CDP. Carbon Disclosure Project (2013). Carbon Disclosure Project report 2013 Australia and New Zealand. Retrieved from https://www.cdp.net/CDPResults/CDP-Australia-NZClimateChange-Report-2013.pdf

CDP. Carbon Disclosure Project (2016a). CDP South Africa water 2016: Water and climate change are closely related. Retrieved from http://www.nbi.org.za/wpcontent/uploads/2016/12/CDP-Water-South-Africa-2016-Infographic-2-Water-and-ClimateAre-Closely-Related.pdf

CDP. Carbon Disclosure Project (2016b). Thirsty business: Why water is vital to climate action. 2016 annual report of corporate water disclosure. London, UK: CDP.

Charlo, M. J., Moya, I., \& Muñoz, A. M. (2013). Sustainable development and corporate financial performance: A study based on the FTSE4GoodIBEX index. Business Strategy and the Environment, 24, 277-288. https://doi.org/10.1002/bse.1824

Cho, C. H., Guidry, R. P., Hageman, A. M., \& Patten, D. M. (2012). Do actions speak louder than words? An empirical investigation of corporate environmental reputation. Accounting, Organizations and Society, 3537, 14-25. https://doi.org/10.1016/j.aos.2011.12.001

Christensen, J. H., Krishna Kumar, K., Aldrian, E., An, S.-I., Cavalcanti, I. F. A., de Castro, M., ... Zhou, T. (2013). Climate phenomena and their relevance for future regional climate change. In T. F. Stocker, D. Qin, G. K. Plattner, M. Tignor, S. K. Allen, J. Boschung, et al. (Eds.), Climate change 2013: The physical science basis. Contribution of Working Group I to the Fifth Assessment Report of the Intergovernmental Panel on Climate Change (pp. 1217-1308). Cambridge: Cambridge University Press. 
Cisneros, J. B. E., Oki, T., Arnell, N. W., Benito, G., Cogley, J. G., Döll, P., Mwakalila, S. S. (2014). Freshwater resources. In C. B. Field, V. R. Barros, D. J. Dokken, K. J. Mach, M. D. Mastrandrea, T. E. Bilir, et al. (Eds.), Climate change 2014: Impacts, adaptation, and vulnerability. Part A: Global and sectoral aspects. Contribution of Working Group II to the Fifth Assessment Report of the Intergovernmental Panel on Climate Change (pp. 229-269). Cambridge: Cambridge University Press.

Comyns, B., Figge, F., Hahn, T., \& Barkemeyer, R. (2013). Sustainability reporting: The role of 'search', 'experience' and 'credence' information. Accounting Forum, 37(3), 231-243. https://doi.org/10.1016/j.49 accfor.2013.04.006

Cubasch, U., Wuebbles, D., Chen, D., Facchini, M. C., Frame, D., Mahowald, N., \& Winther, J.-G. (2013). Introduction. In T. F. Stocker, D. Qin, G.-K Plattner, M. Tignor, S. K. Allen, J. Boschung, et al. (Eds.), Climate change 2013: The physical science basis. Contribution of Working Group I to the Fifth Assessment Report of the Intergovernmental Panel on Climate Change (pp. 119-158). Cambridge: Cambridge University Press.

D'Amico, E., Coluccia, D., Fontana, S., \& Solimene, S. (2016). Factors influencing corporate environmental disclosure. Business Strategy and the Environment, 25, 178-192.

https://doi.org/10.1002/bse.1865

de Colle, S., Henriques, A., \& Sarasvathy, S. (2014). The paradox of corporate social responsibility standards. Journal of Business Ethics, 125(2), 177.

https://doi.org/10.1007/s10551-013-1912-y

De Silva Lokuwaduge, C. S., \& Heenetigala, K. (2017). Integrating environ- mental, social and governance (ESG) disclosure for a sustainable development: An Australian study. Business Strategy and the Environment, 26, 438-450. https://doi.org/10.1002/bse.1927

Deegan, C. (2014). An overview of legitimacy theory as applied within the social and environmental accounting literature. In J. Bebbington, J. Unerman, \& B. O'Dwyer (Eds.), Sustainability Accounting and Account- ability (pp. 248-272). New York: Routledge.

Department of Trade and Industry (2009). Companies Act. Cape Town, South Africa: Department of Trade and Industry.

Du, X., Jian, W., Zeng, Q., \& Du, Y. (2013). Corporate environmental responsibility in polluting industries: Does religion matter? Journal of Business Ethics, 124(3), 485-507. https://doi.org/10.1007/s10551- 013-1888-7

Editorial (2009). Risk management, corporate governance and management accounting: Emerging interdependencies. Management Accounting Research, 20, 2-5. https://doi.org/10.1016/j.mar.2008.11.002 
Epstein, M. J. (2008). Improving social and financial performance in global corporations. In M. J. Epstein (Ed.), Making sustainability work: Best practices in managing and measuring corporate social, environmental, and economic impacts (pp. 19-32). CA: Berrett-Koehler.

FTSE International (2002). FTSE global classification system. London, UK: FTSE International.

Hörisch, J., Johnson, M. P., \& Schaltegger, S. (2015). Implementation of sustainability management and company size: A knowledge-based view. Business Strategy and the Environment, 24, 765-779. https://doi.org/ 10.1002/bse.1844

IoDSA. Institute of Directors in Southern Africa (2002). King Code on Corporate Governance for South Africa. Cape Town, South Africa: IoDSA.

IoDSA. Institute of Directors in Southern Africa (2009). King Code on Corporate Governance for South Africa. Cape Town, South Africa: IoDSA.

IoDSA. Institute of Directors in Southern Africa (2016). King IV Report on Corporate Governance for South Africa (Vol. 2016). Cape Town, South Africa: IoDSA.

IPCC. Intergovernmental Panel on Climate Change (2014). Climate change 2014: Synthesis report - Summary for policymakers. Geneva, Switzerland: IPCC.

IRMSA. Institute of Risk Management South Africa (2015). South Africa risks report. Johannesburg, South Africa, IRMSA.

Jabbour, J., Keita-Ouane, F., Hunsberger, C., Sánchez-Rodríguez, R., Gilruth, P., Patel, N., ... Schwarzer, S. (2012). Internationally agreed environmental goals: A critical evaluation of progress. Environmental Development, 3, 5-24.

https://doi.org/10.1016/j.envdev.2012.05.002

Jizi, M. (2017). The influence of board composition on sustainable development disclosure. Business Strategy and the Environment, 26, 640-655. https://doi.org/10.1002/bse.1943

Jose, A., \& Lee, S. M. (2007). Environmental reporting of global corporations: A content analysis based on website disclosures. Journal of Business Ethics, 72(4), 307-321. https://doi.org/10.1007/s10551- 006-9172-8

JSE (2010). Listing requirements section 13. Johannesburg, South Africa: JSE

Kirtman, B., Power, S. B., Adedoyin, J. A., Boer, G. J., Bojariu, R., Camilloni, I., Wang, H. J. (2013). Near-term climate change. In T. F. Stocker, D. Qin, G.-K. Plattner, M. Tignor, S. K. Allen, J. Boschung, et al. (Eds.), Climate change 2013: The physical science basis. Contribution of Working Group I to the Fifth Assessment Report of the Intergovernmental Panel on Climate Change (pp. 953-1028). Cambridge: Cambridge University Press. 
Kolk, A. (2003). Trends in sustainability reporting by the Fortune Global Business Strategy and the Environment, 12(5), 279-291. https://doi.org/10.1002/bse.370

KPMG (2013). The KPMG Survey of Corporate Responsibility Reporting 2013. Amsterdam, The Netherlands: KPMG.

Lozano, R. (2013). Sustainability inter-linkages in reporting vindicated: A study of European companies. Journal of Cleaner Production, 51, 6 57-65. https://doi.org/10.1016/j.jclepro.2013.01.039

Malherbe, S., \& Segal, N. (2001). Corporate governance in South Africa Trade and Industrial Policy Strategies, 2001 Annual Forum, Johannesburg, South Africa

Mårtensson, K., \& Westerberg, K. (2016). Corporate environmental strategies towards sustainable development. Business Strategy and the Environment, 25, 1-9. https://doi.org/10.1002/bse.1852

Maubane, P., Prinsloo, A., \& Van Rooyen, N. (2014). Sustainability reporting patterns of companies listed on the Johannesburg Securities Exchange. Public Relations Review, 40(2), 153-160. https://doi.org/10.1016/j. pubrev.2014.02.014

Paulraj, A. (2009). Environmental motivations: A classification scheme and its impact on environmental strategies and practices. Business Strategy and the Environment, 18, 453468. https://doi.org/10.1002/bse.612

Peters, G. F., \& Romi, A. M. (2014). Does the voluntary adoption of corporate governance mechanisms improve environmental risk disclosures? Evidence from greenhouse gas emission accounting. Journal of Business Ethics, 125, 637-666.

https://doi.org/10.1007/s10551-013-1886-9

Ramos, T. B., Cecílio, T., Douglas, C. H., \& Caeiro, S. (2013). Corporate sustainability reporting and the relations with evaluation and management frameworks: The Portuguese case. Journal of Cleaner Production, 52, 24 317-328.

https://doi.org/10.1016/j.jclepro.2013.03.002

Romolini, A., Fissi, S., \& Gori, E. (2014). Scoring CSR reporting in listed companies - Evidence from Italian best practices. Corporate Social Responsibility and Environmental Management, 21, 65-81. https://doi.org/10.1002/csr.1299

Searcy, C. (2016). Measuring enterprise sustainability. Business Strategy and the Environment, 25, 120-133. https://doi.org/10.1002/bse.1861

Siebenhüner, B., \& Arnold, M. (2007). Organizational learning to manage sustainable development. Business Strategy and the Environment, 16, 339-353. 
https://doi.org/10.1002/bse.579

Skouloudis, A., Evangelinos, K., \& Kourmousis, F. (2010). Assessing non- financial reports according to the Global Reporting Initiative guidelines: Evidence from Greece. Journal of Cleaner Production, 18(5), 426-438. https://doi.org/10.1016/j.jclepro.2009.11.015

Songini, L., \& Pistoni, A. (2012). Accounting, auditing and control for sustainability. Management Accounting Research, 23(3), 202-204. https:// doi.org/10.1016/j.mar.2012.06.002

SSE Secretariat (2017). How stock exchanges can grow green finance. A voluntary action plan. Sustainable Stock Exchanges Initiative. Retrieved from http://www.sseinitiative.org/data/publications/

Sullivan, R., \& Gouldson, A. (2017). The governance of corporate responses to climate change: An international comparison. Business Strategy and the Environment, 26, 413-425. https://doi.org/10.1002/bse.1925

UN. United Nations (2012). Report of the United Nations Conference on Sustainable Development. In New York: UN.

How to cite this article:

Kitsikopoulos C, Schwaibold U, Taylor DFP. Limited progress in sustainable development: Factors influencing the environmental management and reporting of South African JSE-listed companies. Bus Strat Env. 2018. https://doi.org/10.1002/bse.2176 